\title{
Study of Durum Wheat Genotypes' Response to Drought Stress Conditions
}

\author{
${ }^{\square}$ Majid Khayatnezhad, ${ }^{2}$ Roza Gholamin \\ ${ }^{1,2}$ Young Researchers Club, Ardabil Branch, Islamic Azad University, Ardabil, Iran. \\ Khayatnezhad@gmail.com \\ Rozagholamin@gmail.com
}

Received: 09th September 2020, Accepted: 14th October 2020, Published: 31st October 2020

\begin{abstract}
Several current procedures help farmers overcome or at least manage drought-related challenges, including breeding, selection, and screening; however since the two former procedures may be lengthy and uneconomical, Screening drought-tolerant genotypes for identifying the optimal cultivar for arid lands is the best approach that ensures minimum yield loss. This research experiment attempts to evaluate the adaptability drought-tolerance potential of latesown wheat cultivars in Ardabil, Iran. The study included the following four genotypes in the experiment, designating a water requirement range of 50-70 percent: Leucurum (Tabriz), Melanopus (Cheiltoxm), Leucurum (Germi), and Hordeiforme (Maraghe). Additionally, the control water requirement level was set to $100 \%$. The experiment used MSTAT-C, a tool developed by The University of Michigan for research in the agriculture field, to validate the data concerning stages of growth, grain yield (GY), and the factors contributing to the yield. The decreasing impact of drought-stress was significant on all factors (contributors) related to growth and yield but the harvest index (HI). Additionally, the severity of water stress had the highest impact when under $50 \%$ of the total water requirement condition (TWR $=50 \%$ ). This applied drought stress to the experiment plants also impacted the crop growth stages, which include the days to complete tillering and the days to complete $50 \%$ heading, although the impacts on the latter were more significant. Different growth and yield traits caused the cultivars in the experiment to respond variably. For instance, Leucurum (Tabriz) had the minimum days to complete tillering and heading, while Hordeiforme (Maraghe) represented the highest height and dry biomass accumulation. Melanopus (Cheiltoxm) reported maximum values for grain yield and yield contributors except for spike length that was maximum in Leucurum (Tabriz). Field findings suggest Melanopus (Cheiltoxm) has remarkable growth and yield traits, which allow for its cultivation in drylands with limited access to water supplies for irrigation.
\end{abstract}

\section{Keywords \\ Drought Stress, Durum Wheat, Late Planting}

\section{Introduction}

A suitable whole grain, Durum wheat (Triticum turgidum L. subsp. durum Desf) is a critical food crop with extensive applications in the food sector, thanks to its dense, non-sticky, gluten-heavy dough (Khayatnezhad, Khayatnezhad, \& Gholamin, 2012), and (Mohammadi \& Sharifi et al., 2014). Recently, the main agenda of durum wheat breeding programs worldwide is finding and developing cultivars with improved grain yield (Gholamin \& Khayatnezhad 2012, Ayed-Slama \& Bouhaouel et al., 2018). Water shortage stress and the associated challenges are a major set of abiotic factors damaging and constraining the international production of wheat. (Richards \& Rebetzke et al., 2002). A recent research survey concerning about 102 million hectares of wheat farms in the developing countries, which are equal to $47 \%$ of the global or $89 \%$ of the wheat area in the developing countries, indicated that water deficit stress is one of the major limiting factors of wheat production, causing an estimated annual yield loss of 19\%-50\% (Khayatnezhad \& Gholamin 2012), and (Pokhrel \& Baral et al., 2013). Nevertheless, the promising potential of screening genotypes in search of crops with optimal drought-resistant traits suitable for rain-fed agriculture is yet to be explored (Pokhrel \& Baral et al., 2013). A staple source of food and famously susceptible to water deficit conditions, wheat is known to provide about $19 \%$ of food energy and about $21 \%$ of daily dietary protein and fulfill the need of more than $1 / 3$ of the world's population. (Bratspies, 2014) and (Chaves \& Oliveira, 2004). There is a limited list of 'major producers' of wheat in the world, including the USA, Russia, China, France, Canada, Pakistan, India, Germany, and Australia (Bratspies, 2014). Sadly, researchers report that wheat farms in both the developing and developed countries are now facing harsh environmental conditions as at least 99 million hectares of farms in the developing countries and 60 million hectares in the developed countries are currently dealing with water-related stress (Rajaram 2000). The world needs a significant increase (an estimated 50\%) in grain yields of crops like wheat, maize, and rice to fulfill the anticipated food requirements by 2050 (Godfray \& Beddington et al., 2010). 
The environmental types of stress that plants tolerate can have two main origins: biotic and abiotic. Biotic stress is defined as the stress caused by 'living' things such as unfriendly organisms, various pathogens, weeds, and fungi. Abiotic stress, on the other hand, though, is caused by 'non-living' things, including air and water pollutants, extreme (low or high) temperatures, water deficit conditions, physical damage, drought, intense light conditions, and salinity (Vickers \& Gershenzon et al., 2009). Arguably, the most influential source of abiotic stress is water deficit conditions. (Vickers \& Gershenzon et al., 2009). Theoretically, a plant's stage of development determines how drought can severely impact its physiology, morphology, growth, and yield traits (Hossain and DA SILVA 2012). In this experiment, the stress caused by water deficit had a significant impact on the internal water status of the crop cells as it decreased RWC, water, and osmotic potential, which subsequently caused a decrease in the turgor potential, closure of stomata, and hindered wheat growth and cell enlargement (Jaleel \& Sankar et al., 2008; Akram, 2011). The evolvement of resistance to drought in plants is a complex phenomenon as it is the product of the combination of several genetic, physiological, and biochemical mechanisms (Erdei, 2002; Mattana \& Biazzi et al., 2005). Environmental stress is not the only reason for the low yields of wheat farms in Ardabil, as delayed cultivation has often played a prominent role in the decline. Research experiments should focus on identifying and evaluating new cultivars with short-term maturity, water-conserving, and drought-resistant properties to make wheat production economical. This experiment is an attempt to evaluate the growth and yield potentials of late-sown wheat genotypes under different levels of drought-induced environmental stress in Ardabil, Iran.

\section{Material and Methods}

This study designed an experiment to evaluate the drought tolerance potential of four durum wheat cultivars, as depicted in Table 1, under drought stress conditions in the agricultural experiment station (AES) at The Islamic Azad University in 2016. Drought stress was applied by providing $50 \%$ and $75 \%$ of the volume of TWR, while the full water requirement was used as the control amount. The experiment was arranged in an RCB design with split plot arrangements and three replications. The experiment applied water requirement to the main plots, while cultivars were in the subplots. The experiment field's soil consisted of only $0.7 \%$ organic material content. Table 2 represents the physicochemical properties of the collected soil samples.

Table 1: Genotypes Name and Regions.

\begin{tabular}{ccc}
\hline No & Genotype & Region \\
\hline 1 & Leucurum (Tabriz) & Iran \\
2 & Melanopus (Cheiltoxm) & Iran \\
3 & Leucurum (Germi) & Azerbaijan \\
5 & Hordeiforme (Maraghe) & Azerbaijan \\
\hline
\end{tabular}

Table 2: Results Obtained from Analyzing the Sample Soils

\begin{tabular}{|c|c|c|c|c|c|c|c|c|c|c|c|c|}
\hline \multirow{2}{*}{$\begin{array}{l}\text { Soil } \\
\text { Type }\end{array}$} & \multicolumn{3}{|c|}{ Soil Texture } & \multirow{2}{*}{ 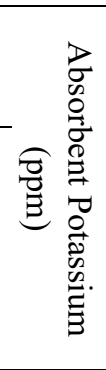 } & \multirow{2}{*}{ 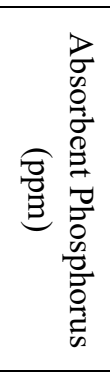 } & \multirow{2}{*}{ 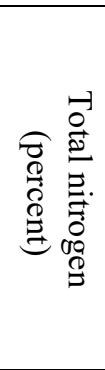 } & \multirow{2}{*}{ 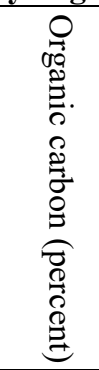 } & \multirow{2}{*}{ 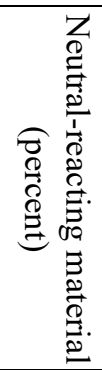 } & \multirow{2}{*}{ 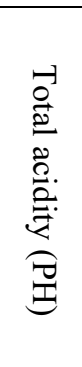 } & \multirow{2}{*}{ 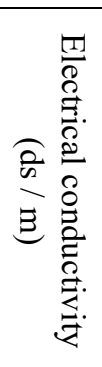 } & \multirow{2}{*}{ 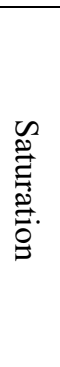 } & \multirow{2}{*}{ 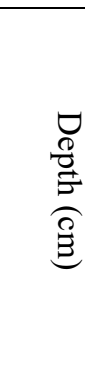 } \\
\hline & Sand & Silt & Clay & & & & & & & & & \\
\hline $\begin{array}{l}\text { Clay } \\
\text { loam }\end{array}$ & 31 & 41 & 28 & 460 & 4.8 & 0.103 & 0.97 & 4.8 & 7.8 & 2.6 & 48 & $0-30$ \\
\hline Clay & 40 & 36 & 24 & 290 & 2 & 0.056 & 0.47 & 7 & 8.2 & 2.4 & 45 & $30-60$ \\
\hline
\end{tabular}

The research experiment was conducted using 10 wheat cultivars in RCB design under and stress rain-fed irrigation and non-stress irrigation conditions with four replications.

Stress treatments included:

Complete irrigation: defined as meeting all the water requirements of the plant at various stages of growth.

Limited irrigation: defined as providing a plant's needed volume of water requirements until anthesis, after which a moderate drought is applied until the terminal stages of growth with 50-70 percent normal irrigation. 
The planting design included five rows placed $2 \mathrm{~cm}$ apart for each genotype. Distances between irrigated and drought blocks were $2 \mathrm{~m}$ but were $3 \mathrm{~m}$ between the two irrigated or drought blocks. To accelerate the germination of cultivars, the rhizosphere profile was moistened with irrigation. The experiment used flood irrigation at the harvest time to prevent border effect, eliminating $50 \mathrm{~cm}$ of each row from both sides to harvest. Next, the study measured the following traits: spike length, GPS, TGW, and HI.

The data concerning growth and yield were recorded to predict the crop's response to the levels of drought stress for delayed plantation in arid conditions. Plant height was recorded with a measuring scale, while days to complete tillering and 50\% heading were counted to differentiate cultivars in terms of their sensitivity to drought stress based on their vegetative and reproductive growth stages. The study also estimated the difference between cultivars concerning LAI, DMA or dry matter accumulation, and the capacity for productive tillers. Besides, the following criteria were also recorded: wheat yield and yield contributors, including spike length, GPS, TGW, and HI. The study used plant height as a reference for measuring spike height length values but used the electric balance to measure and record GW and GY.

The study analyzed the collected data of these experiments as an average $\S$ standard error for two technical and three experimental clones and then used factorial ANOVA. Then, the experiment computed the values of $F$ to investigate two interactions and the main impacts. The study then used Duncan's MRT to evaluate the differences between the average of treatments at $\mathrm{p}<0.05$. This research used MSTAT-C, SPSS, and SAS (Institute 1999; Bihani \& Char et al., 2011).

\section{Results}

\section{Wheat Growth}

Based on the statistical analysis of results, drought-induced stress in plants has direct, significant ( $\mathrm{p} \leq 0.05)$, negative impacts on plant height, LAI, the accumulation of dry biomass, the number of productive tillers, and the days to complete tillering and $50 \%$ heading. The inherent traits of cultivars had significant impacts $(\mathrm{p} \leq 0.05)$ on plant height, productive tillers, and the accumulation of dry biomass. The impact of drought-induced stress $\times$ cultivars interaction was also significant $(\mathrm{p} \leq 0.05)$ for studied growth traits except for LAI and plant height. The observations suggested that the maximum plant height and other growth traits values belonged to unstressed plots. It was seen that increasing drought stress levels significantly decreased growth traits. Also, the application $50 \%$ water requirement, regardless of cultivars' inherent capabilities (sensitive or tolerant), was responsible for the greatest decrease in plant growth. The impacts of drought-induced stress proved insignificant on plant height, days to $50 \%$ heading, and the accumulation of dry biomass in the comparison between two forms of water requriement treatment (50\% and $75 \%)$. Also, different growth traits in clutivars responded differently to drought priming. For instance, Hordeiforme (Maraghe) demosntrated the highest plant height. Also, Melanopus (Cheiltoxm) had the highest number of productive tillers under non-stress plots, while Leucurum (Germi) reported the highest number under severe drought stress (with 50\% water requirement treatment). While Hordeiforme (Maraghe) took maximum days to complete tillering, Melanopus (Cheiltoxm) was the last one to complete 50\% heading. Also, Hordeiforme (Maraghe) and Leucurum (Germi) not only indicated the highest dry matter accumulation but also the maximum LAI for non-stressed plots, whereas Melanopus (Cheiltoxm), demonstrated the highest LAI under stress plots, as depicted in Table 3.

Table 3: Response of different Wheat Genotypes to Applied Levels of Water Requirements

\begin{tabular}{|c|c|c|c|c|c|c|c|}
\hline \multirow{2}{*}{ Conditions } & \multicolumn{7}{|c|}{ Treatments } \\
\hline & Genotypes & $\begin{array}{r}\text { Plant } \\
\text { height }\end{array}$ & $\begin{array}{l}\text { Productive } \\
\text { tiller } \mathrm{m}-2\end{array}$ & $\begin{array}{l}\text { Days to } \\
\text { tillering }\end{array}$ & $\begin{array}{r}\text { Days to } \\
50 \% \\
\text { heading } \\
\end{array}$ & $\begin{array}{l}\text { Dry matter } \\
\text { accumulation }\end{array}$ & $\begin{array}{r}\text { Leaf } \\
\text { area } \\
\text { index }\end{array}$ \\
\hline \multirow{4}{*}{ Full irrigation } & 1 & 51.75 & 388.24 & 27.15 & 61.52 & 6556.67 & 2.03 \\
\hline & 2 & 64.21 & 470.43 & 27.01 & 71.02 & 7801.34 & 2.68 \\
\hline & 3 & 58.24 & 408.15 & 28.96 & 66.24 & 6235.12 & 2.83 \\
\hline & 4 & 60.35 & 300.24 & 29.36 & 63.17 & 8125.78 & 1.89 \\
\hline Drought Stress & 1 & 47.21 & 229.58 & 25.03 & 56.82 & 5241.26 & 1.62 \\
\hline \multirow[t]{3}{*}{$75 \%$} & 2 & 47.01 & 273.18 & 22.14 & 60.21 & 5032.36 & 2.67 \\
\hline & 3 & 46.52 & 259.68 & 25.62 & 57.26 & 4827.84 & 2.21 \\
\hline & 4 & 50.03 & 203.25 & 24.89 & 55.21 & 5235.18 & 1.91 \\
\hline Drought Stress & 1 & 46.54 & 197.54 & 19.21 & 47.36 & 4044.21 & 1.61 \\
\hline \multirow[t]{3}{*}{$50 \%$} & 2 & 41.98 & 189.63 & 21.24 & 56.82 & 4487.94 & 1.94 \\
\hline & 3 & 44.15 & 224.01 & 20.17 & 52.87 & 4865.17 & 1.79 \\
\hline & 4 & 49.21 & 148.25 & 20.36 & 47.99 & 5028.14 & 1.41 \\
\hline
\end{tabular}




\section{Grain Yield and Yield Contributors}

Drought stress highly impacted $(\mathrm{p} \leq 0.01)$ the spike length, GPS, TGW, GY, and HI. Also, the interaction of drought stress $\times$ cultivar was highly significant $(p \leq 0.01)$ for GPS and HI. Nevertheless, this interaction was significant $(p \leq 0.05)$ for TGW and non-significant for spike length and grain yield. The observations also indicated that, while increasing the drought stress decreased all the yield contributing traits, HI continued to increase. Furthermore, drought stress had the most severe negative impact on TGW and GY. Except for spike length, all other Melanopus (Cheiltoxm) produced the highest values for the studied traits under drought stress. Leucurum (Tabriz) had the highest spike length. The Cultivar Leucurum (Germi) was the second-best after Melanopus (Cheiltoxm) and was most of the time nonsignificant with Melanopus (Cheiltoxm) for the studied yield parameters (Table 4).

Table 4: Effect of Water Stress on Yield and Yield Components of Four Wheat Genotypes

\begin{tabular}{|c|c|c|c|c|c|c|c|}
\hline Irrigation & Genotype & $\begin{array}{r}\text { Spike length } \\
(\mathrm{cm})\end{array}$ & Grains spike ${ }^{-1}$ & 1000 & $\begin{array}{r}\text { grain } \\
\text { weight } \\
\text { (g) }\end{array}$ & $\begin{array}{r}\text { Grain } \\
\text { yield } \\
\left(\mathrm{Kg} \mathrm{ha}^{-1}\right)\end{array}$ & $\begin{array}{r}\text { Harvest } \\
\text { Index }\end{array}$ \\
\hline \multirow[t]{4}{*}{$100 \%$} & 1 & 10.46 & 48.47 & & 41.27 & 2547 & 28.65 \\
\hline & 2 & 9.51 & 47.02 & & 40.98 & 2798 & 27.01 \\
\hline & 3 & 9.54 & 50.36 & & 43.01 & 2657 & 29.65 \\
\hline & 4 & 9.63 & 41.84 & & 35.69 & 2261 & 21.84 \\
\hline \multirow[t]{4}{*}{$75 \%$} & 1 & 9.01 & 42.65 & & 34.2 & 1986 & 27.52 \\
\hline & 2 & 8.79 & 40.57 & & 37.62 & 2387 & 31.25 \\
\hline & 3 & 7.69 & 42.03 & & 39.01 & 2241 & 31.96 \\
\hline & 4 & 7.92 & 34.99 & & 34.87 & 1935 & 26.57 \\
\hline \multirow[t]{9}{*}{$50 \%$} & 1 & 7.64 & 32.87 & & 24.97 & 1674 & 29.52 \\
\hline & 2 & 6.98 & 38.01 & & 28.63 & 1932 & 30.01 \\
\hline & 3 & 7.21 & 37.12 & & 24.87 & 1824 & 27.52 \\
\hline & 4 & 7.22 & 34.02 & & 24.21 & 1596 & 23.2 \\
\hline & $\mathrm{DS}$ & $* *$ & $* *$ & & $* *$ & $*$ & * \\
\hline & $\mathrm{C}$ & $*$ & $* *$ & & $* *$ & $* *$ & $* *$ \\
\hline & $\mathrm{DS} \times \mathrm{C}$ & ns & $* *$ & & $*$ & ns & $* *$ \\
\hline & $\mathrm{CV}$ & 8.19 & 7.52 & & 11.02 & 5.98 & 8.52 \\
\hline & LSD $p \leq 0.05$ & 1.08 & 3.05 & & 2.98 & 119 & 1.85 \\
\hline
\end{tabular}

*significant at $\mathrm{p} \leq 0.05, * *$ significant at $\mathrm{p} \leq 0.01,{ }^{\mathrm{ns}}$ non-significant, ${ }^{\mathrm{DS}}$ Drought stress, ${ }^{\mathrm{C}} \mathrm{Cultivar},{ }^{\mathrm{CV}} \mathrm{Coefficient}$ of variation and ${ }^{\mathrm{LSD}}$ Least significant difference.

\section{Discussion}

Drought causes the highest level of destructive stress that can impede optimal production. The impact of the drought is a function of intensity, drought duration, and crops' growth stage. Findings suggest wheat is most susceptible to stress during the anthesis stage. In a relevant research study, Alghabari and his co-researchers stated that the adverse impacts of drought on yield and growth on wheat crops and attributed crops' different responses to environmental stress to their innate capabilities (Alghabari \& Ihsan et al., 2015). The growth traits are considered as a crop's critical indicators of stress tolerance and adaptability potential (Sanghera \& Thind, 2014). In comparison with other cultivars in this research, Hordeiforme (Maraghe) demonstrated the maximum height but the lowest grain yield. Conversely, Melanopus (Cheiltoxm) demonstrated the shortest height with the highest grain yield. Other factors were vital in the development of tolerance to drought, including the plant's potential delay in heading and maturation, a higher (LAI), or leaf area index (Dalirie \& Sharifi et al., 2010). Bearing such traits meant Melanopus (Cheiltoxm) could remain green longer. Also, a greater LAI allowed for higher levels of photosynthates and assimilation to the grain. The short stature of the Melanopus (Cheiltoxm) and Leucurum (Germi) was due to the expression of reduced height genes. Other factors like GPS or grains per spike, GY rain yield, and TGW also were important determiners of the cultivar's potential for drought tolerance (Denčić \& Kastori et al., 2000). As both of these traits are related to the reproductive stage, and any decline in these traits can directly reduce final grain yield. The stress induced by drought in the experiment caused a significant reduction of these traits; however, the growth traits of more tolerant Melanopus (Cheiltoxm) and Leucurum (Germi) did not change significantly (minimum reduction) in comparison with the less tolerant Leucurum (Tabriz) and Hordeiforme (Maraghe). 


\section{Conclusion}

The conventional breeding methods of identifying and developing crops with drought-resistant properties are impractical as they are both costly and time-taking, and above all, the process is complicated. Thus, investigating existing varieties to identify cultivars with optimal drought-tolerance by screening under arid conditions seems to be a viable solution. In this research experiment, Melanopus (Cheiltoxm) demonstrated promising drought-tolerant properties and suitable adaptability to stress conditions in Ardabil with proper growth and grain yield traits. Thus, findings propose Melanopus as a feasible candidate for cultivation in the region. Furthermore, the strong and promising genetic backbone of Melanopus allows for future research into finding new drought-resistant crops.

\section{References}

[1] Akram, M. (2011). "Growth and yield components of wheat under water stress of different growth stages." Bangladesh Journal of Agricultural Research 36(3): 455-468.

[2] Alghabari, F., M. Z. Ihsan, S. Hussain, G. Aishia and I. Daur (2015). "Effect of Rht alleles on wheat grain yield and quality under high temperature and drought stress during booting and anthesis." Environmental Science and Pollution Research 22(20): 15506-15515.

[3] Ayed-Slama, O., I. Bouhaouel, Z. Chamekh, Y. Trifa, A. Sahli, N. B. Aissa and H. Slim-Amara (2018). "Genetic variation of salt-stressed durum wheat (Triticum turgidum subsp. durum Desf.) genotypes under field conditions and gynogenetic capacity." Journal of Genetic Engineering and Biotechnology 16(1): 161-167.

[4] Bihani, P., B. Char and S. Bhargava (2011). "Transgenic expression of sorghum DREB2 in rice improves tolerance and yield under water limitation." The Journal of Agricultural Science 149(1): 95.

[5] Bratspies, R. M. (2014). "Food, technology and hunger." Law, Culture and the Humanities 10(2): 212-224.

[6] Dalirie, M. S., R. S. Sharifi and S. Farzaneh (2010). "Evaluation of yield, dry matter accumulation and leaf area index in wheat genotypes as affected by terminal drought stress." Notulae Botanicae Horti Agrobotanici Cluj-Napoca 38(1): 182-186.

[7] Denčić, S., R. Kastori, B. Kobiljski and B. Duggan (2000). "Evaluation of grain yield and its components in wheat cultivars and landraces under near optimal and drought conditions." Euphytica 113(1): 43-52.

[8] Erdei, L. (2002). "Osmotic stress responses of wheat species and cultivars differing in drought tolerance: some interesting genes (advices for gene hunting)." Acta Biologica Szegediensis 46(3-4): 63-65.

[9] Gholamin, R. and M. Khayatnezhad (2012). "Effect of different levels of manganese fertilizer and drought stress on yield and agronomic use efficiency of fertilizer in durum wheat in Ardabil." Journal of Food, Agriculture \& Environment 10(2 part 3): 1326-1328.

[10] Godfray, H. C. J., J. R. Beddington, I. R. Crute, L. Haddad, D. Lawrence, J. F. Muir, J. Pretty, S. Robinson, S. M. Thomas and C. Toulmin (2010). "Food security: the challenge of feeding 9 billion people." science 327(5967): $812-818$.

[11] Hossain, A. and J. A. T. DA SILVA (2012). "Phenology, growth and yield of three wheat (Triticum aestivum L.) varieties as affected by high temperature stress." Notulae Scientia Biologicae 4(3): 97-109.

Institute, S. A. S. (1999). SAS/STAT User's guide, version 8, SAS Institute.

[12] Jaleel, C. A., B. Sankar, P. Murali, M. Gomathinayagam, G. Lakshmanan and R. Panneerselvam (2008). "Water deficit stress effects on reactive oxygen metabolism in Catharanthus roseus; impacts on ajmalicine accumulation." Colloids and Surfaces B: Biointerfaces 62(1): 105-111.

[13] Khayatnezhad, M. (2012). "Evaluation of the reaction of durum wheat genotypes (Triticum durum Desf.) to drought conditions using various stress tolerance indices." African Journal of Microbiology Research 6(20): 43154323 .

[14] Khayatnezhad, M. and R. Gholamin (2012). "The effect of drought stress on leaf chlorophyll content and stress resistance in maize cultivars (Zea mays)." African Journal of Microbiology Research 6(12): 2844-2848.

[15] Khayatnezhad, M. and R. Gholamin (2012). "Effect of nitrogen fertilizer levels on different planting remobilization of dry matter of durum wheat varieties Seimareh." African Journal of Microbiology Research 6(7): 1534-1539.

[16] Mattana, M., E. Biazzi, R. Consonni, F. Locatelli, C. Vannini, S. Provera and I. Coraggio (2005). "Overexpression of Osmyb4 enhances compatible solute accumulation and increases stress tolerance of Arabidopsis thaliana." Physiologia Plantarum 125(2): 212-223.

[17] Mohammadi, M., P. Sharifi and R. Karimizadeh (2014). "Stability analysis of durum wheat genotypes by regression parameteres in dryland conditions." Acta Universitatis Agriculturae et Silviculturae Mendelianae Brunensis 62(5): 1049-1056. 
[18] Pokhrel, D., K. Baral, B. R. Ojha, S. K. Ghimirey and M. P. Pandey (2013). "Screening Wheat Genotypes for Drought Tolerance and Co-relation Study among Morpho-physiological Traits." Journal of Agriculture and Environment 14: 65-77.

[19] Rajaram, S. (2000). Prospects and promise of wheat breeding in the 21 st century. Wheat in a Global Environment. International Wheat Conference, 6; Budapest, Hungary; 5-9 Jun 2000. Abstracts of oral and poster presentations. ${ }^{\wedge}$ TWheat in a Global Environment. International Wheat Conference, 6; Budapest, Hungary; 5-9 Jun 2000. Abstracts of oral and poster presentations ${ }^{\wedge}$ ABedo, Z ${ }^{\wedge}$ AMartonvásár (Hungary)^ BAgricultural Research Institute of the Hungarian Academy of Sciences^ ${ }^{\wedge} 2000$.

[20] Richards, R., G. Rebetzke, A. Condon and A. Van Herwaarden (2002). "Breeding opportunities for increasing the efficiency of water use and crop yield in temperate cereals." Crop science 42(1): 111-121.

[21] Sanghera, A. K. and S. Thind (2014). "Screening of wheat genotypes at seedling stage for their potential to withstand heat stress on the basis of membrane thermosenstivity tests." International Journal of Agriculture and Crop Sciences (IJACS) 7(9): 640-645.

[22] Vickers, C. E., J. Gershenzon, M. T. Lerdau and F. Loreto (2009). "A unified mechanism of action for volatile isoprenoids in plant abiotic stress." Nature chemical biology 5(5): 283-291. 